\title{
With Feathers: Effects of Copyright and Ownership on Scholarly Publishing
}

\section{Ann Okerson}

\begin{abstract}
Editor's note: This article is the fourth part of a series on scholarly communications and serials prices.

The copyright legislation of the United States was conceived to promote the "progress of science and useful arts." While copyright law, which defines ownership of published works, is effective for trade and mass market publications, its effect upon scholarly publishing can act as a barrier to the wide sharing of ideas. The reasons for this perception are discussed in relation to both current paper and electronic publishing practices. Broader sharing of scholarly ideas can be successful through addressing the larger arena of university and scholarly distribution and ownership of intellectual ideas. The increased number of electronic journals and research and academic electronic networks offers hope for the future.
\end{abstract}

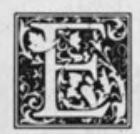

mily Dickinson wrote in a celebrated poem that " 'Hope' is the thing with feathers." Why a thing with feathers? Because like the bird the metaphor evokes, hope is soft and fluffy. Hope is probably small. It is elusive; it lights suddenly and then vanishes. It sings sweetly, but is hard to capture. This paper is about hope for the publishing system, specifically the current scholarly publishing system, some of whose characteristics, particularly ownership, place this species on at least the moderately endangered list.

We sense from annually published Association of American Publishers (AAP) statistics that the general arena of paper and other trade and mass market publications is thriving, that the market is large enough and the competition great enough so that the overall publishing system remains largely affordable and accessible. It fulfills its mandate of providing hardcover and paperback books, magazines, videos, and computer games to meet broadly based public needs. Price inflation is at tolerable, affordable levels.

Popular books are widely available and either stay in print or recycle secondhand in a cottage industry, out-of-print marketplace. These days, librarians worry a great deal more about scholarly publishing and seek hope for it, because it is becoming dysfunctional and endangered. For the purposes of this paper, scholarly publishing communicates largely or mainly to researchers, scholars, and academics, or seeks to communicate within the community where these scholars work-that is, within academe-to students and colleagues. At times the system communi-

Ann Okerson is Director of the Office of Scientific and Academic Publishing at the Association of Research Libraries, Washington, D.C. 20036. This paper is adapted from a session given at the November 1990 AMIGOS conference entitled "Electronic Publishing: Who Owns What, When?" 
cates passively. To wit, academic writing may be perceived as unread and possibly uninteresting, but it is purchased and stored by academic libraries as a record of what has been thought about a variety of subjects, as "the body of knowledge." Strictly speaking, scholarly publishing is, for the most part, limited to the segment of the industry that has become almost exclusively dependent on researchers for authorship and on academic or scholarly libraries for income. ${ }^{1}$

A special and anomalous characteristic of scholarly publishing is that its financial fountainhead is largely public or governmental, funding being given either directly to public institutions or less directly to private ones. For example, grants from the private sector or tuitions are tax deductible. Unlike the situation with trade publications, with scholarly publications (1) the government funds researchers, (2) the government funds the libraries that purchase researchers' output, and (3) in between (1) and (2), the publication process (authoring of articles and refereeing or peer reviewing of them, both substantial components of the publication effort and both performed by scholars without pay) gives scholarly output to publishers, which may sell it at a price of their choosing. Because of its public-based funding, scholarly information may be viewed as government information, or information for the "public good." I would argue that like government information, it ought to be widely available as a matter of public policy, rather than treated as a market commodity.

The present scholarly publishing system is in danger for four reasons, most of them entwined with the notion of ownership:

1. Prices of printed books and journals are increasing far more rapidly than national inflation rates, and individual libraries can afford a decreasing percentage of them. Coincidentally, the majority of at least scientific publishing is in private, for-profit ownership-ownership that charges higher unit costs to purchasers. Many forprofit scholarly journals are so expensive individuals cannot afford them.
2. The academic world rewards quantity in publication. Thus, an increasing number of publications is produced, often in small runs. Librarians feel compelled to buy them, although quality is often perceived as mediocre and (as recent revisitations to citation data indicate) many materials may go unread. While their journals generally include the titles with higher citation impact factors, universities and learned societies are increasingly minority scholarly publishers, at least in the sciences. For instance, more than 70 percent of the journal titles indexed in the Institute for Scientific Information's Science Citation Index are produced and most likely owned by the for-profit sector.

3. Via the conventions of scholarly publishing, copyright of writings from the largely not-for-profit educational sector is assigned to publishers that resell intellectual efforts back to the educational sector. Value is added, but when priced for purchase, particularly by commercial owners, academe grumbles that the price is not worth it or is unaffordable.

4. Although technology offers greater opportunities for creating and transmitting information and for writing, it simultaneously poses unresolved problems in just about every other area, including ownership.

Such stresses imperil the higher education, research, and library functions. Additionally, research library collections and customer service depend on both ready and eternal accessibility to intellectual property and ideas. By eternal, I mean that in addition to establishing breadth and depth of collections, research libraries are committed to preserving recorded knowledge over a long time.

En route to analyzing the relationship of ownership to scholarly publishing, I will first briefly consider the problems inherent in ownership as defined by copyright law and copyright law's effect on scholarly publishing in paper forms. Then I will extend that discussion to 
emerging electronic forms. Finally, I will discuss the more general notion of ownership and how it might effectively resolve some of the strains on the present scholarly publishing system.

\section{IS U.S. COPYRIGHT LAW OPTIMALLY EFFECTIVE FOR SCHOLARLY AND ACADEMIC PUBLISHING?}

In its precise definition, "ownership" is legal title or proprietorship. Our legal system has created various frameworks for describing different kinds of ownership: for example, real estate law for land; corporate law for businesses; trademark law for product identifiers; patent law for inventions; and copyright law for authored works. Therefore, copyright law creates a definition of intellectual property that has identity. That identity is "works fixed in a medium of expression," such as writings, music, and pictures. Copyright law gives the creator the right to produce or reproduce, to distribute, perform, or display, for the duration of the copyright period, fifty years and up. In the United States, more than in most other countries, the rights of the creator become secondary to the rights of the publisher, as the creator signs over copyright (ownership) to the publisher. Such assignment is the norm in scholarly journals and monographs, whose authors are generally not paid by the publisher for either initial publication or subsequent copying revenues. It is generally recognized that authors publish to spread their ideas and reputations and that very little scholarship is read enough to have any hope of attaining best-seller status.

Copyright law is meant to protect the expression of an idea while encouraging the dissemination of the idea itself. Accordingly, its fundamental objective is to balance rewarding the creator with circulating intellectual products. The stated intent of the authors of the 1909 Copyright Act was to "promote the progress of science and the useful arts." 2 Much of the writing about the Copyright Act compliments it on striking that balance. However, several problems exist.

\section{Copyright law provides incentives to authors only in "normal" (i.e., trade) market conditions.}

Copyright works for trade books, but it does not work for scholarly publications because the market is limited and purchasing incentives are very different. The recent dramatic increases in quantity and price of scholarly journals indicate that the system for producing and distributing scholarship does not adhere to free market laws. Each scholarly article and book is unique. The potential pool of purchasers is specialized and relatively small, and the vague definition of scholarly "need" leads to the tendency for the small consumer group to seek completeness in purchasing scholarly works. ${ }^{3}$ Once ordered, journal subscriptions have been difficult to abandon. The academic marketplace orders for quality and prestige over pages for dollar. Therefore, the market for scholarly publishing is inelastic: demand for journals does not respond significantly to price increases. The more reputable titles have the potential for growing rapidly in price, absorbing a larger proportion of the institutional budget, and remaining sacrosanct despite adverse financial performance.

Furthermore, the creator or author, by tradition writing for recognition of ideas and for academic reward, assigns copyright or ownership to a publisher. No money changes hands. A typical scientific journal copyright statement transfers from the owner to the publisher rights for paper publication, reprints, microform, electronic media, and (some statements say) media that have not yet evolved. For the risk and added value of production, the publisher owns the work, the rights to it, and the profit from it. Because scholarly works are not interchangeable, the owner of each work has, in effect, a monopoly on that unique product. Those desiring to purchase goods from a monopoly must rely on the good will of that monopoly in setting prices.

The most severe indications of dysfunction and overpricing in the scholarly world occur in the sciences, where studies repeatedly show that certain types of pub- 
lishers-mainly large commercial producers that have no direct interest in the knowledge itself and whose principal stake is profit-raise prices at least twice as rapidly as standard national inflation increases. ${ }^{4}$ This phenomenon is in direct contrast to the practices of the not-forprofit sector and other smaller or humanistic publishers. A recent LSU study of three major international scientific publishers shows that they doubled prices in about six years while doubling the size of journal content in about twelve years. ${ }^{5}$

Nonetheless, academic institutions are subject to strong internal pressure to keep up with significant scholarly publications. Judgments on significance can be drawn from some imprecise assessment of the status of the editorial board or of the quality of the publisher. These scholarly publications are thought to be vital to scholarly communication, education, and research, as well as to the body of knowledge. Because budgets have limitations, such collecting efforts are increasingly doomed. Cancellations occur at the rate of 2 to 3 percent per year, scholarly journal publishers inform us; scholarly monographic press runs are greatly reduced; in research libraries, journal collections displace book purchases. ${ }^{6}$ Purchasing is top heavy in sciences over humanities, leading to what the Modern Languages Association (MLA) has termed for the title of its next annual conference the "Crisis in Humanities Publishing." 7 When part of the system becomes out of proportion, it displaces other parts.

\section{Copyright law does not provide for} broad copying of works created at public expense. It effectively converts public property to private property.

This statement has a significant exception. Article 105 of the Copyright Act states, "Copyright protection under this title is not available for any work of the United States Government." In article 101 "Definitions," a "work of the United States Government" is a work prepared by an officer or employee of the U.S. government as part of that person's official duties. ${ }^{8}$ Authors of such work cannot sign over rights to producers. Instead of signing a copyright transfer form, such authors assert that the work was done under the conditions of article 105. A statement to that effect appears on the printed piece, and users may copy the work freely. Article 105 does not include work produced under government grants, for example from the Defense Department, the Department of Energy, NASA, or the National Institutes of Health. Agreat deal of academic and laboratory scientific research in the United States is accomplished with such funding. Authors of work so produced observe conventional academic ownership policies - embedded in tradition-and are free to reassign ownership. Additionally, if a work is produced by a government employee in collaboration with a nongovernment employee, the nongovernment employee still transfers copyright to a publisher. Furthermore, article 105 does not apply to state-funded activity.

The recent dramatic increases in quantity and price of scholarly journals indicate that the system for producing and distributing scholarship does not adhere to free market laws.

Generally, whatever the funding sources, authored work done in universities and research facilities is the creator's, and in the process of publication that creator signs over ownership. It is not clear what would happen should authors refuse to transfer copyright. If a work is exciting enough to the publisher, it will presumably be printed according to the author's restrictions. Publishers believe that nonownership of scholarly works would quickly undercut their livelihood and profitability. If an author allowed unrestricted copyright, it would be possible, theoretically, for institutions to share a single book or subscription and copy freely. If the author retained copyright, there would remain the logistics problem of individual authors handling rights and permissions to their work. Such a function could, of course, be absorbed by a central university office that clears permissions campuswide. 
Not infrequently, the copying or recopying of scholarly materials pits readers or librarians against publishers. Because of the quasi-public nature of research findings, the readers and librarians feel morally entitled to generous reproduction allotments, publishers to generous compensation for copying. In general, publishers, booksellers, and librarians adjust definitions of "fair use" through sometimes uneasy compromise or arbitration-rarely through the courts. Librarians tend to be conservatively law abiding, so most of the squabbles and legal battles occur between merchants and publishers rather than between librarians and publishers. Indeed, Kenneth Crews, in his recent dissertation for the UCLA library school, discovered the "overwhelming tendency of librarians to choose narrower fair use standards. Interviews with librarians revealed an acute sensitivity to liability possibilities, even without exposure to actual threats at their campuses." Still, the provision for systematic, collective ownership of publicly supported research is a significant omission from the Copyright Act.

The above discussion has not dealt with the provisions of fair use. If, aslibrarians believe, many ideas are generated through the generosity of the public purse and that they ought to be shared generously as a public good, the kind of fair use described in the Copyright Act would have to be rethought. Fair use and the way it has been defined by the CONTU guidelines (no more than five copies from the same book or journal title-not issue or edition-by any one library in any year) may place some libraries, in cancelling expensive journals and sharing titles or collections, in transgression of the Copyright Act.

Another curious situation relates directly to the public support of a great deal of research and of the libraries that store and service that research. The situation is that printed materials, especially scholarly ones, go out of print quite rapidly as publishers produce shorter press runs of monographs and maintain smaller inventories. The publishers' original support through printing and distribu- tion deserves fair compensation, but publishers do not find it profitable to support those publications in the long term. Probably a vast majority of what is photocopied and shared by libraries is no longer purchasable. Thus, the responsibility for maintaining, in effect, publishers' back stock or warehouses falls on the publicly supported and not-for-profit institutions called libraries that are nonetheless expected to reimburse the original publishers. ${ }^{10}$ This oxymoron is not addressed adequately by either the information community or the guidelines that elaborate upon fair use.

\section{Copyright law does not treat emerg- ing technological capabilities and is- sues adequately.}

As the expression of scholarly ideas becomes less and less affordable, the question of whether the 1909 or 1976 copyright law, or any copyright law, is the right law for sharing scholarship is again raised in some quarters. Scholars like Harlan Cleveland write of the "fraying fictions of patent and copyright law." $\mathrm{He}$ asserts that it has been possible to sustain the distinction between ideas and their expression-albeit with controversy-in the print age. With the enormous changes wrought by ever quicker and cheaper, pervasive electronic communications means, Cleveland champions the information commons and the radically different rules for sharing information. In an oft-quoted editorial, he asks, "How can intellectual property be protected? The question contains the seeds of its own confusion: it's the wrong verb about the wrong noun."11

Recently, it has become fashionable to speak of the end of copyright because, in addition to its existing flaws and limitations, current copyright law does not address the realities of the kind of scholarly communication increasingly available in the electronic information age. ${ }^{12}$ Reasons advocated for this view are as follows:

- In electronic communications, it can be impossible to distinguish between ideas and the expression of those ideas. In a software program written in some language or configuration, 
how does one reproduce the idea, which is permissible by copyright law, without reproducing the expression of that idea, which is not?

- In electronic communications, copying becomes indispensable to even reading an idea. According to the International Federation of Reproduction Rights Organization's Working Group on Electrocopying, any storage, display, manipulation, dissemination, and reproduction of an electronically stored work would constitute copying. ${ }^{13}$ According to the IFRRO, any act of reading would incur a charge. Yet existing copyright law does not constrain the use of an idea or of the work itself; it simply sets rules about copying.

- Copying can be easily metered only the first time information is read. After that, it may become difficult to determine whether a work has been recopied or forwarded to other users. While means of deterring unauthorized usage can be created, users will avoid purchase of copy-protected materials if other options are available. Auto-deterrents can fail: they can damage users' software or disks, and they can be decoded. Copying hesitations deter publishers from using new technologies that are potentially quicker and cheaper for users to access.

- Works can be combined, recombined, accessed, and used in ways not anticipated by the original creator or compiler. Consider, for example, hypertext. O. B. Hardison in his book Disappearing through the Skylight describes reading Shakespeare's The Tempest in hypertext. ${ }^{14}$ The initial scene of the shipwreck offers the "reader" the ability to delve into explications of shipwrecks, maps of the New World, London theaters, and magic. Can such an experience be remotely like taking the play home to read one evening? Can readers be said to have shared the experience of reading The Tempest when each pursued different discourses and enrichments during the course of reading the play?

- Electronic technologies encourage widespread communication, data sharing, and collaborative work. The number of authors may be sizable or it may, indeed, become very difficult to determine precisely who the authors are. Their intentions or wishes about reuse may vary. Work may be amended and annotated. Its packaging disappears. Interactive "journals" appear. The sharing enabled in the electronic environment leads to what has been termed the "collaboratory." 15

\section{RESPONSES TO PROBLEMS IN COPYRIGHT LAW}

Clearly, substantial controversy exists about the 1976 copyright law, to some degree for traditional paper publishing and to a much greater degree for electronic communications. Resolutions put forward by various experts include:

- Use the existing law, amending it as needed, recognizing that amendments take a long time, lag behind technological developments, and produce statements that immediately displease a number of the parties involved.

- Supplement the law with contracts or licenses that grant permission that might otherwise violate existing laws. Licenses, as for CD-ROM, might limit a purchaser's sharing of information he or she rents but does not own. Or they might authorize a central agency, such as the Copyright Clearance Center (CCC), to collect user fees which are returned to the legal owners.

- Adopt a sui generis option. Robert Oakley of Georgetown University's law library suggests that some things simply do not fit existing intellectual property laws and that the law might, rather than stretching itself, create new laws that meet the special requirements of each mode and situation. ${ }^{16}$

- Throw the act out or revise it completely. ${ }^{17}$

In 1886, Congress asked the Office of Technology Assessment (OTA) what would be the appropriate course of action to take in regard to copyright law, given the emergence of new technologies. In its report, the OTA argued that new technology needs could be solved only by significant changes in the intellectual property system. Describing the 
thinking behind the OTA's report entitled Intellectual Property Rights in an Age of Electronics and Information, Linda Garcia explains that the 1976 copyright law, in spite of attempting to build in language for any technology as yet unintroduced, has been unsuccessful. That law protects "original works of authorship fixed in any tangible medium of expression now known or later developed. ${ }^{18}$ Nonetheless, no sooner was the new law passed than it needed to be amended, first for software, then for audio- and videocassettes.

OTA staff reasoned as follows: First, the printing press gave rise to the need for permission to copy, or copyright, because it became possible to reproduce works, and that process created a marketplace. The relatively limited number of publishers had the presses and skills to copy and market. New technologies expanded this ability to copy to virtually everyone, quickly. Second, intellectual property and the development of technology are part of the social system. Technology affects society and its values, behaviors, and expectations, and these in turn affect the law. Because technology is introducing sweeping changes, intellectual property needs to be fundamentally reconsidered, along with related concerns of authority, access, privacy, integrity, and liability.

\section{WHERE DO WE GO FROM HERE, OR IS THERE OWNERSHIP BEYOND COPYRIGHT?}

It is fair now to offer a personal view of intellectual property law, specifically copyright. Defining ownership of the expression of ideas is a particularly useful concept, and we need such a law. As someone once remarked, an individual has to know who the giants are in order to stand on their shoulders or even to cry on them. The law does indeed have flaws and limitations, and it lags behind societal developments. Nonetheless, it enables intellectual work to be produced and disseminated in a comparatively orderly fashion. Discarding the law would cause chaos. The current U.S. copyright legislation was devised after much bloodletting, anguish, and compromise, and the fundamental idea will not be abandoned. It was written to be technology neutral, which suggests that revisions are likely to attempt to incorporate new technologies rather than to except them or treat them specially. Some suggest that the copyright law could be altered to exempt scholarly ideas or to place them within a special category. For instance, some propose that scholarly articles might legally come out from under copyright provision in a very short time period, such as two to five years. However, such a compromise seems unlikely for the small, hard-to-define subset of writing or application known as scholarship. The copyright law will persevere; we will continue amending it; we will work with it.

That opinion offers no solution to the vexing problems for scholarly publications as outlined above. Given the limitations of existing copyright legislation in advancement of the scholarly arts and sciences, and the time and difficulty of changing such complex legislation, with its many proponents and opponents, are there other solutions? As we have discussed, being the creator of scholarly writings has offered relatively little hope because of the way in which scholars and creators have reassigned ownership. The funder of research, whether university, state agency, or federal government agency, has by tradition not retained ownership for the public good.

Hope does exist, however, and it rests in changing the ownership of scholarly ideas as opposed to or in addition to modifying copyright legislation. Those who speak about the "crisis in scholarly publishing" encourage a change in ownership, as opposed to copyright, by nudging the not-for-profit sector- university presses and scholarly and professional societies - to become central again to the distribution of scholarly information. Librarians have been assertive in suggesting that such groups "take back" publications that have been contracted out to the commercial sector, that they become greater risk-takers in starting new publications. In parallel, the library community is encouraging academics to write 
for the not-for-profit sector when that is possible. The purpose of encouraging movement to the not-for-profit sector is to make materials more accessible through the greater affordability that seems to result from not-for-profit ownership of scholarly writings. It would also strengthen competition.

As the expression of scholarly ideas becomes less and less affordable, the question of whether ... any copyright law, is the right law for sharing scholarship is again raised in some quarters.

Closer to the issue of retaining ownership of ideas is the suggestion that academic administrators provide incentives for their own university presses to make a stronger showing in scholarly communication and for their faculty to publish in university outlets. This process would keep a larger proportion of scholarly copyrights within academia and enable universities to make generous sharing possible among their libraries, without running afoul of fair use provisions and the CONTU guidelines. Another feather of hope is in reminding authors that they may grant limited or restricted rights to publishers. This modification could be effective if universities created standard copyright assignment forms that any of their faculty could routinely submit to publishers-forms that would limit the extent of rights by time or format. No single scholar could be as effective as an entire university or a group of universities that choose to retain rights to their institution's authored output.

A few such shifts are occurring, but fundamental changes take a long time. It may be that not-for-profit publishers have lost too much ground over the past three decades to large for-profit paper publishers. At a November 1990 meeting of the Coalition for Networked Information (CNI), Stuart Lynn of Cornell University reported that only 15 percent of scholarly publication today is done from universities. And that is a generous 15 percent, including the work of individual departments on campuses. However, electronic networks and complementary technologies are in place in many government agencies and are increasingly pervasive in academic institutions; they offer hope. Government and academe are spending hundreds of millions of dollars a year to "wire" the nation. Champions of a National Research and Education Network (NREN) have put forward legislation that will speed up the linkage, acceleration, and development of such networks. This massive investment is clearly offering information-generating and -distributing opportunities to the education and research sector. Universities, colleges, and research laboratories could find themselves in a position of Samsonian strength as owners of the means of scholarly and research communication and distribution-provided that at least some content ownership is retained within academia, whether by authors or authors in collaboration with their institutions. That is to say that at least academe has a genuine window of opportunity.

\section{"I HAVE A DREAM" - OF UNIVERSITY-BASED PUBLISHING}

Several librarians have dreamed about university-established networks in scholarly publishing. An early statement was made by Patricia Battin, now president of the Commission on Preservation and Access. ${ }^{19}$ In the April 12, 1989, issue of the Chronicle of Higher Education, Richard Dougherty imagined universities regaining control over their own scholarly output through commitments to computer and telecommunications technologies. "Why not marry," he asks, "the technological capabilities of computer centers with the expertise of university presses as producers and libraries as retailers and distributors, to expand the university's role?" ${ }^{\prime 20}$ An additional-probably the most valuablebenefit would be regaining copyright control for the universities.

In a widely discussed article, Sharon Rogers and Charlene Hurt asserted that scholarly journals are obsolete as the primary means of communicating current 
scholarly findings. Their call also was for a university-based publishing system into which scholars from all disciplines would place their findings, according to subject. The works would be available to all readers, who would be free to comment on-in effect, peer review-the pieces. After six months, a work would be revised and finally reviewed by a board of colleagues, and the article would be entered into the system with annotations about its quality. Rogers and Hurt imagined such a system, constructed from the top down, to be possible within five years. ${ }^{21}$

The copyright law will persevere; we will continue amending it; we will work with it.

In June of 1990, Jerome Yavarkovsky, from the State Library of New York, exhorted at the start-up meeting of the ARL/Cause/EDUCOM Coalition for Networked Information that "it is time to talk about joining institutions in a vast and powerful system for scholarly communication.... In traditional terms, we are the authors, the editors, the paper mills, the printing presses, the binderies, and the readers. We are part of a perfect, vertically integrated enterprise. ... Our universities and other research organizations have the choice: Control electronic publishing to our economic and intellectual advantage, or surrender the initiative and the future of scholarly communication to others." 22

A statement of vision presented at the CNI November 3-5, 1991, meeting called for research and educational institutions to seize the opportunities presented by technology and the opportunities to print knowledge on demand. It described Information Technology Imaging (ITI) projects and discussions, and it referred to pioneering projects at Cornell, Harvard, Princeton, Virginia Tech, and the University of Michigan in partnership with Xerox to produce publication on demand. ${ }^{23}$

The Association of Research Libraries (ARL) October 1990 membership meet- ing featured a daylong interactive program called "The Future of Public Services in the Year 2000." Futurist Robert Weber presented five different scenarios for sources of information. In one of them, "University Consortium Creates 'Info-Online'," he sketched a consortium of forty leading universities creating the largest online repository in the world, in cooperation with university presses, societies, and other consortia. The result would be potentially low-cost online information and heavily subsidized access to scholars and students. ${ }^{24}$

Apparently, the idea of universityowned and -based scholarly publishing is in the air, or at least in the air breathed by librarians and academics. Exciting digitizing projects being ventured at the National Agricultural Library (NAL) and at North Carolina State; calls for project proposals by $\mathrm{CNI}$; and statements of intent from major universities about becoming electronic information providers-such projects abound and offer hope. Networked publishing is also exciting and energizing individual academics. The first edition of an ARL directory of scholarly networked publications (summer 1991) lists some thirty academic journals, twice that many newsletters, and hundreds of academic discussion lists. Much of this work has flowered in recent months.

\section{ELECTRONIC "JOURNALS"}

On October 8, 1990, ARL convened a meeting of refereed electronic journal editors with the North Carolina State University Library as host institution..$^{25}$ In attendance were editors from eight of the e-journals either already in existence or proposed, as well as collections, public services, technical services, and systems librarians. The projects range among disciplines: adult education, postmodern culture, communications, hospitality studies, and librarianship. Two science journals are due to appear next year. The lag exists because of technical developments needed to transmit nontext data.

The projects share a great many characteristics. They are from the not-for- 
profit sector, all but one originating at the grass roots: faculty members from within universities. All are either free or comparatively inexpensive. Those that have produced issues are experiencing rapid circulation growth. Innovative, experimental trailblazers in networked publishing, they are relatively unknown. The creators are excited and impatient, with a philosophy of 'let's put out some issues and let the problems be solved as they come along." All the university-based projects are generous about ownership, imposing either no copying constraints or very generous allowances. One electronic journal editor commented on ownership of ideas:

Perhaps [some]one might try to purloin an idea and publish it as his own. So what? The peers saw it first and know whence it came, and where and when, with the archive to confirm it.... The few big ideas that there are will not fail to be attributed to their true source as a result of the net. As to the many little ones, the "minimal publishable units," well, I suppose that a scholar can spend his time trying to protect those too - or he can be less stingy with them in the hope that something bigger might be spawned by the interaction. ... I am inclined to think that for the really creative thinker, ideas are not in short supply. . . E Einstein was asked in the ' 50 s by some tiresome journalist what activity he was usually engaged in when he got his creative ideas, and he replied that he really couldn't say, because he had only one or two creative ideas in his entire lifetime. ${ }^{26}$

Everywhere in the 1990s there seems to be the whiff of a changed scholarly publishing system, shareable, affordable, and accessible, its main function to spread ideas as widely and quickly as possible. The vision is possible, of course, because of a revitalization of two relatively ancient principles: that scholars own and share ideas and that a university's role is to distribute those ideas widely. Will the vision come to pass? Can essentially materialistic individuals and organizations conceive a new and different system? Would universities be any more altruistic as scholarly information publishers than those publishers some now accuse of overcharging or even price gouging? "The answer," as on a sampler in the apartment of a friend, "is a definite maybe, and that's for certain."

\section{ARE UNIVERSITIES ALTRUISTIC?}

Dougherty promoted the idea of university-based publishing as one that makes a lot of dollars. Rogers and Hurt argued more practically: to whit, the savings effected from funding spent last year by academic libraries could support such a publishing system. (About 40 percent of the 1.25 billion acquisitions dollars spent by the United States' 3,500 academic libraries comes from the ninetyfour ARL university libraries. ${ }^{27}$ The proportion of ARL university library budgets spent on serials runs about 18.7 percent. ${ }^{28}$ For the remainder of the 3,500 academic libraries in the United States the percentage is only slightly less: about 16.7 percent. $^{29}$ ) In supporting universitybased publishing, universities could reduce the enormous amounts of money expended in buying back their scholarship and probably improve the effectiveness of communicating scholarly ideas.

Let us speculate that the silver cloud has a potentially stormy lining. Certain difficulties are involved in universities' undertaking publishing or commercial ventures. One difficulty is universities' comparative lack of experience in managing businesslike, risky, capital-intensive ventures. Academic years, budget structures, charters, and legislation may not lend themselves readily to such enterprises. Universities have, after all, gradually given over publishing of their intellectual output to outsiders. Perhaps intellectual ownership and distribution within the academy still does not strike enough of a chord to interest those who must fund and organize shifts in academic philosophy.

Another difficulty grows out of the relatively new fashion for collaboration, coalitions, and partnerships, specifically between the for-profit and university 
sectors. The University of Southern California's textbook project is a partnership between the university and McGraw publishers. Cornell and the Commission for Preservation and Access are collaborating with Xerox in a pilot project to test advanced technologies for recording deteriorating books as digital images. ${ }^{30}$ In a broader endeavor, Merit, a consortium of IBM, MCI, and state-supported universities in Michigan, is forming a not-for-profit company called Advanced Network and Services, Inc. (ANS) to manage and operate the federally funded NSF network backbone. ${ }^{31}$ Several universities have ties to research and development corporations, particularly in biomedicine.

\section{Current copyright law does not address the realities of the kind of scholarly communication increasingly available in the electronic informa- tion age.}

Such alliances are formed for the common good. Universities providebrainpower and corporations provide equipment and technology to achievea project neither could accomplish alone. It might, devilishly, be reasoned that corporations also seek significant tax write-offs, which they can achieve with the fig leaf of a not-forprofit company, and that universities seek funding to make up for the increasing costs of doing research and the inability of the usual tax and tuition sources to provide funds. Already emerging from some partnerships are concerns about universities' financial vulnerability in ventures that may fail and about conflicts of interest in relationships. Financial interests may interfere with the university's rigor and honesty, its role as social critic and advocate for the public good.

Questions abound. How can faculty, with a stake in the outcome of a particular product, be detached and objective about it? They are not necessarily making altruistic choices about where to publish their articles, as we have seen. Does the loss of tax revenues, as for- profit organizations mutate into not-forprofit enterprises, exacerbate the problem of inadequate funding for education and social programs? If so, ultimately we will all pay higher taxes. Maybe we ought to agree to do that at the outset and not mix a milkshake of commerce and education. Does the creation of large profits in the not-for-profit sector make the institution vulnerable to a change in tax status (the lawsuit between Dialog and the American Chemical Society raises this issue.)?

Of course, electronic distribution is already changing ownership models substantially. Because of the ease of copying concerns outlined earlier in this paper, publishers tend to retain ownership of electronic materials. This is done in charging "by the drink" as users access remotely stored information. Or libraries purchase electronic data packaged as CD-ROM, for which they generally pay a subscription, not for ownership, but for a license that restricts the breadth of distribution of that information. Legally, ownership remains with the publisher, and the library leases the information. Theoretically, at least, the CD-ROMs must be returned if the library cancels.

This publishers' "insurance policy" potentially leaves libraries owning nothing at all, except for older and print materials. The newly emerging model of library nonownership, especially via networking, in which libraries do not even see a physical product, has profound implications for universities' intellectual birthright, libraries' services, and the body of knowledge. Cooperative collection development and wide resource sharing among educational and research institutions may become virtually impossible in the electronic age, as long as the sole copyright owners continue to be external publishers. These implications, in theory, can be fully addressed and resolved if authors and their institutions, rather than distanced commercial publishers, were intellectual property owners.

Having spent a little time cautioning about universities as owners, I still have 
the well-founded hope that universities will choose to become nurturers and players in scholarly output. Their vital participation presents a tremendous opportunity for scholarly publishing and for competition within the system. I have the hope that, as owners of publishing systems, universities would use that ownership in good faith and good will to share ideas quickly and inexpensively. The prospects are far better than any we have had in the past forty years to accomplish this freer access to information and knowledge. We need people with idealism, enthusiasm, and conscience to promote changes in ownership of ideas and their distribution, and librarians are key in such a movement.

Woody Allen said that Emily Dickinson was wrong. Hope is not the thing with feathers - the thing with feathers is my cousin, and we sent him to an analyst in Vienna. Whether with or without feathers, we do have hope. In Annie Hall, Woody Allen-commenting to Diane Keaton, who has parked her car quite a distance from the sidewalk-said, "We can walk to the curb from here." If we move scholarly publishing in from the busy commercial street and closer to the curb and to home, we will have accomplished something worth our while.

\section{REFERENCES AND NOTES}

1. Adapted from Karen Hunter, "A Publisher's Perspective," Library Acquisitions: Practice and Theory 14:5 (1990).

2. The purpose of the 1909 act, often quoted in writings about it, was stated as follows: The enactment of copyright legislation by Congress under the terms of the Constitution is not based on any natural right that the author has in his writings, for the Supreme Court has held that such rights as he has are purely statutory rights, but on the ground that the welfare of the public will be served and progress of science and useful arts will be promoted.... Not primarily for the benefit of the author, but primarily for the benefit of the public such rights are given. Not that any particular class of citizens, however worthy, may benefit, but because the policy is believed to be for the benefit of the great body of people, in that it will stimulate writing and invention to give some bonus to authors and inventors.

Quoted in the U.S. Congress, Office of Technology Assessment, Intellectual Property Rights in an Age of Electronics and Information, OTA-CIT-302 (Washington, D.C.: U.S. Government Printing Office, April 1986), p.3.

3. Two recent articles provide insights into ingredients affecting the output and pricing of scholarly journals. David W. Lewis, "Economics of the Scholarly Journal," College E Research Libraries 50:674-88 (Nov. 1989), describes the economic characteristics of scholarly journals and their tendency toward "natural monopoly." Gary D. Byrd, in his excellent article, "An Economic 'Commons' Tragedy for Research Libraries: Scholarly Journal Publishing and Pricing Trends," College \& Research Libraries 51:184-95 (May 1990), observes the damaging effects of unreined writing and purchasing on both pricing and human knowledge.

4. Substantial documentation appears for this assertion. See the annual price indexes published in Library Journal every April 15th by the American Library Association's Library Materials Price Index Committee; the Faxon Company's "Periodical Prices Updates" published from time to time in Serials Librarian; and Ann Okerson, "Of Making Many Books There Is No End," in Report of the ARL Serials Prices Project (Washington, D.C.: Assn. of Research Libraries, 1989), particularly fig.1, p.7-8 and the review of discipline-based pricing studies, p.30-31.

5. Chuck Hamaker, "Costs of Scientific Journals Increase at Double the Rate of Research Costs," ARL: A Bimonthly Newsletter of Research Library Issues and Actions 153:1-2 (Nov. 7, 1990).

6. For a written description of this trend in scientific journals in the early 1980 s, see Howard J. Sanders, "Troubled Times for Scientific Journals," C \& EN 6:31-40 (May 30, 1983). Conversations at the Society for Scholarly Publishing 9th Annual Top Management Round Table in Alexandria, Virginia, September 12-14, 1990, reaffirmed these 
drop-off rates. At a convocation held at the University of Colorado in April 1991, a major STM publisher affirmed recent cancellation rates edging up to 5 percent for its journals.

7. There are no precise published data about this situation, which is nonetheless an assertion widely made within the research library community. See Okerson, "Of Making Many Books," p.21.

8. These definitions are taken from Copyright Law of the United States of America, contained in Title 17 of the United States Code, Revised to September 30, 1987.

9. Kenneth D. Crews, "Large-Scale Study of University Copyright Standards Reveals Surprising Trends in Policy-Development and Legal Interpretations," press release from the Graduate School of Library and Information Science, University of California-Los Angeles, August 1, 1990.

10. The seed of this thought comes from conversations with John R. Haak, director of libraries at the University of Hawaii, at a recent Association of Research Libraries membership meeting.

11. Harlan Cleveland, "How Can Intellectual Property' Be 'Protected?'" Change 21:10-11 (May/June 1989).

12. Robert J. Kost, "The End of Copyright," in Intellectual Property Rights in an Electronic Age, Proceedings of the Library of Congress Network Advisory Committee Meeting, April 22-24, 1987 (Washington, D.C.: Library of Congress), p.19-25. In fact, the suggestion of abolishing or radically changing copyright law resurfaces in many recent critiques of the law, such as in the proceedings of the above meeting, in the Network Advisory Council meeting of 1988, in U.S. Congress, Office of Technology Assessment, Intellectual Property Rights, and in several important pieces in the May/June 1989 issue of Change: Francis Dummer Fisher, "The Electronic Lumberyard and Builders' Rights: Technology, Copyrights, Patents, and Academe," and Steven W. Gilbert and Peter Lyman, "Intellectual Property in the Information Age: Issues beyond the Copyright Law," Change 21:12-34 (May/June 1989).

13. Report of the IFRRO Working Group on Electrocopying, submitted by Charles Clark, IFRRO Chairman, at IFRRO's 1989 Annual General Meeting, Rome, October 17-20, 1989.

14. O. B. Hardison, Disappearing through the Skylight (New York: Viking, 1989), p.263.

15. This concept is developed in Towards a National Collaboratory, the report of an invitational workshop at Rockefeller University, March 17-18, 1989.

16. Robert L. Oakley, "Intellectual Property Issues and Information Networks: A Background Report," in Intellectual Property Issues in the Library Network Context, Proceedings of the Library of Congress Network Advisory Committee Meeting, March 23-25, 1988 (Washington, D.C.: Library of Congress, 1989) p.46-47.

17. Fisher, "The Electronic Lumberyard," passim; and Gilbert and Lyman, "Intellectual Property," passim.

18. D. Linda Garcia, "Information Exchange: The Impact of Scholarly Communication," EDUCOM Review 25:28-32 (Fall 1990).

19. Patricia Battin, "The Library: Centre of the Restructured University," Current Issues in Higher Education 84:25-31 (1983).

20. Richard M. Dougherty, "To Meet the Crisis in Journal Costs, Universities Must Reassert Their Role in Scholarly Publishing," Chronicle of Higher Education 35:A52 (April 12, 1989).

21. Sharon J. Rogers and Charlene S. Hurt, "How Scholarly Communication Should Work in the 21st Century," Chronicle of Higher Education, 35:A56 (Oct. 18, 1989).

22. Reprinted as Jerome Yavarkovsky, "A University-Based Electronic Publishing Network," EDUCOM Review 25:14-20 (Fall 1990).

23. Steering Committee, Coalition for Networked Information, "Information Technology Imaging: A Vision of a New Advanced Networking Utility," in Resources Binder, handed out for CNI Fall 1990 Task Force Meeting, Washington, D.C., November 3-5, 1990.

24. Background information forming a portion of the 117th Association of Research Libraries Membership Meeting, session of October 25, 1990. Weber and Northeast Consulting Resources, Inc., Boston, Massachusetts, have trademarked the concept of "future mapping," and Weber has custom-written scenarios for other information-as- 
sociated groups, such as the Society for Scholarly Publishing (November 1989 Round Table) and the Association of American Publishers, Professional and Society Publishing Division (February 1990 Annual Meeting). A description of the scenario approach appears in "The Academic Enterprise in the 21st Century: The Impact of Computing," ICPSR Bulletin 1-6 (May 1990).

25. "ARL and North Carolina State University Library Convene Symposium of Electronic Journal Editors," ARL: A Bimonthly Newsletter of Research Library Issues and Actions, no.153:7 (Nov. 7, 1990).

26. E-mail correspondence of Stevan Harnad, editor of the journal Behavioral and Brain Sciences, as well as the refereed electronic squibb journal PSYCOLOQUY, shared with ARL.

27. Ann Okerson and Kendon Stubbs, "The Library Doomsday Machine," Publishers Weekly, 238:36-7 (Feb. 8, 1991).

28. Derived from ARL Statistics, 1988-89, (Washington, D.C.: Assn. of Research Libraries, 1990).

29. U.S. Department of Education, National Center for Education Statistics, Academic Libraries: 1988, NCES 90-374 (Washington, D.C.: U.S. Dept. of Education, 1988), p.iii.

30. "Cornell, Xerox, and the Commission Join in Book Preservation Project," Newsletter of the Commission on Preservation and Access (Aug. 1990).

31. "Merit, IBM, MCI Form New Company," Link Newsletter 3:4 (Sept. 1990). 
